Check for updates

Cite this: Mater. Adv., 2020 1,2401

Received 8th July 2020,

Accepted 28th August 2020

DOI: $10.1039 / \mathrm{d} 0 \mathrm{ma} 00489 \mathrm{~h}$

rsc.li/materials-advances

\section{A novel NIR fluorescent probe for fast detection and imaging of methionine sulfoxide reductase $A$ in lysosome of living cells $\dagger$}

\author{
Jin Gong, ${ }^{a b}$ Chang Liu, ${ }^{a}$ Songtao Cai, ${ }^{a b}$ Song He, ${ }^{a}$ Liancheng Zhao $^{\text {ab }}$ and \\ Xianshun Zeng (iD *ab
}

\begin{abstract}
Methionine sulfoxide reductases (Msrs) play special roles in protecting proteins from oxidative damage caused by reactive species and repairing MetSO residues in proteins/peptides. However, current probes for Msrs fail to target lysosomes and exhibit a relatively slow response and short emission wavelengths (less than $580 \mathrm{~nm}$ ). Herein, we reported a novel lysosome-targeted NIR fluorescent probe RBSO for fast detection and imaging Msr A by extending the linear $\pi$-conjugated system of the probe via the $\mathrm{S}_{N} A r^{\mathrm{H}}$ reaction. As expected, RBSO exhibited high selectivity and high sensitivity for the rapid detection of Msr A in real-time via a specific Msr A-triggered methylsulfinyl reduction reaction. Importantly, RBSO was cell-membrane permeable and capable of specifically distributing in lysosomes, and thus detects Msr A in real-time there, providing a potential tool for monitoring Msr A activity in lysosomes of living cells.
\end{abstract}

\section{Introduction}

The methyl chains of methionine (Met) in proteins/peptides are among the most susceptible to oxidation by reactive oxygen species (hydrogen peroxide and hypochlorous acid), reactive nitrogen species and enzymes, leading to the formation of methionine sulfoxide (MetSO) residues. ${ }^{1}$ Meanwhile methylthio groups in many drugs and natural compounds can also be oxidized to methylsulfinyl groups. ${ }^{2}$ Oxidation of Met can disrupt the structure and function of proteins, and play a significant role in the development of diseases associated with oxidative damage protein accumulation, including aging-related neurodegenerative diseases (Alzheimer's and Parkinson's diseases) and cancer. ${ }^{3}$ Since Met has a chiral center at sulfur, it produces two different diastereomers, methionine-S-sulfoxide (Met-S-SO) epimer and methionine- $R$-sulfoxide (Met- $R$-SO) epimer. Methionine sulfoxide reductase (Msr), an important enzyme responsible for the reduction of free and protein-bound MetSO to Met, plays a special role in protecting proteins from oxidative damage caused by reactive species and repairing MetSO residues in proteins/peptides. ${ }^{4}$ Msrs have a wide range of substrate specificities and can reduce various methyl sulfoxide-containing molecules, ranging from protein-bound

\footnotetext{
${ }^{a}$ Tianjin Key Laboratory for Photoelectric Materials and Devices, School of Materials Science \& Engineering, Tianjin University of Technology, Tianjin, 300384, China. E-mail: xshzeng@tjut.edu.cn

${ }^{b}$ School of Materials Science and Engineering, Harbin Institute of Technology, Harbin, 150001, China

$\dagger$ Electronic supplementary information (ESI) available. See DOI: 10.1039/d0ma00489h
}

MetSO residues to several small molecules, such as dimethyl sulfoxide, sulforaphane and methionine sulfoxide. ${ }^{5}$ Msr A and Msr B are two major isoforms of the Msr family and specifically reduce the Met-S-SO epimer and Met- $R$-SO epimer, respectively, and the genes for these two proteins are located within the same operon in many bacteria. ${ }^{6}$ The physiological electron donor for Msrs is the thioredoxin (Trx) system which, in vitro, can be replaced by 1,4-dithiothreitol (DTT) or 1,4-dithioerythritol (DTE). ${ }^{7}$ Although Msr plays an important role in the regulating a variety of cellular events, the lack of effective tools to detect their activity hinders further exploration of the enzymes under physiological or pathophysiological conditions.

In recent years, small molecule fluorescent probe technology has attracted much more attention due to its high selectivity, high sensitivity, simplicity of implementation, real-time, in situ detection, etc. ${ }^{8}$ Generally, the intramolecular charge transfer (ICT) mechanism is a versatile strategy for designing fluorescent probes. ${ }^{9}$ Up to now, all three reported paradigmatic fluorescent probes for monitoring Msr activity were developed by the reduction induced ICT mechanism (Scheme 1). ${ }^{10}$ However, they still bear some limitations, such as the short emission wavelengths (less than $580 \mathrm{~nm}$ ), the slow reduction of Msr probes (30 min) and non-organelle targeting, which limit their biological imaging applications. ${ }^{10}$ The development of probes capable of detecting analytes in the near-infrared (NIR) region $(>650 \mathrm{~nm}$ ) is particularly important for imaging applications because it can avoid auto-fluorescence interference of biological backgrounds, increase tissue penetration depth, and reduce photodamage to living samples. ${ }^{11}$ In addition, there are few reports on the 
Previous:

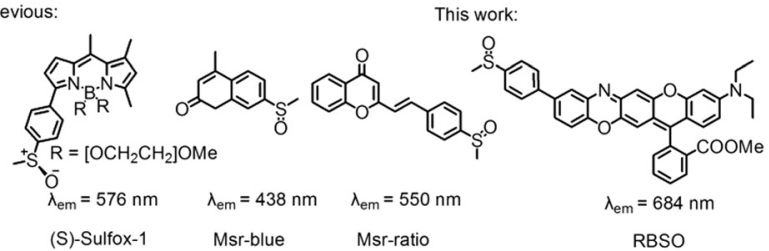

Scheme 1 Structures of the Msr A probe.

distribution of Msr A in cells, and opinions about its distribution are diverse. Vougier et al. believed that Msr A was located in the mitochondria and cytoplasm by purifying the rat liver. ${ }^{12}$ Gladyshev's group found that Msr A was mainly distributed in the cytoplasm..$^{13}$ Therefore, the design and development of organelle-targeted NIR fluorescent probes for real-time monitoring Msrs activity in vivo is important for exploring enzyme production and transfer processes.

Moskovitz's group has shown that mammalian Msr A has high enzymatic activity against $p$-tolylmethyl sulfoxide in vitro, while the substitution of methyl with the phenyl group completely suppresses the catalytic activity, probably due to the excessive steric hindrance of the substrate. ${ }^{14}$ In addition, our group has revealed that rectilinearly extended $\pi$-conjugate of the rhodamine scaffold by engaging a unique intramolecular nucleophilic substitution of aromatic hydrogen $\left(\mathrm{S}_{\mathrm{N}} \mathrm{Ar}^{\mathrm{H}}\right)$ strategy effectively enlarged the emission wavelength. ${ }^{15}$ Herein, we reported a novel lysosometargeted NIR fluorescent probe RBSO for fast detection and imaging Msr A by extending the linear $\pi$-conjugated system of the probe via the $\mathrm{S}_{\mathrm{N}} \mathrm{Ar}^{\mathrm{H}}$ reaction. As expected, RBSO exhibited high selectivity and high sensitivity for the rapid detection of Msr A in real-time via a specific Msr A-triggered methylsulfinyl reduction reaction. Importantly, RBSO was cell-membrane permeable and capable of specifically distributing in lysosomes, and thus detects Msr A in real-time there, providing a potential tool for monitoring Msr A activity in lysosomes of living cells.

\section{Results and discussion}

\section{Molecular synthesis}

Probe RBSO was synthesized according to the procedures in Scheme 2. As shown in Scheme 2, the key intermediate $\mathbf{R B}$ was synthesized starting from 4-bromo-1-fluoro-2-nitrobenzene and

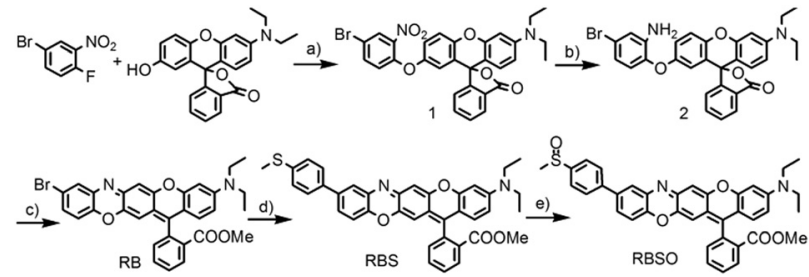

Scheme 2 Synthesis of RBSO. Reagents and conditions: (a) $\mathrm{K}_{2} \mathrm{CO}_{3}, \mathrm{DMF}$ $80^{\circ} \mathrm{C}, 8 \mathrm{~h}$; (b) $\mathrm{SnCl}_{2}, \mathrm{HCl}, \mathrm{MeOH}$, reflux, $8 \mathrm{~h}$; (c) $\mathrm{H}_{2} \mathrm{SO}_{4}, \mathrm{MeOH}$, reflux, 4 h; EtOAc, $\mathrm{K}_{2} \mathrm{CO}_{3}, 40{ }^{\circ} \mathrm{C}$, overnight; (d) $\mathrm{Pd}\left(\mathrm{PPh}_{3}\right)_{4}$, toluene, $\mathrm{K}_{2} \mathrm{CO}_{3}$, 4-(methylthio)phenylboronic acid, reflux, $48 \mathrm{~h}$; (e) $m$-CPBA, DCM, $0{ }^{\circ} \mathrm{C}$ to room temperature.
$3^{\prime}$-(diethylamino)-7'-hydroxyspiro[isobenzofuran-1(3H), $9^{\prime}-[9 H]$ xanthen]-3-one through three steps with a moderate yield. The detailed reaction reagents and conditions are depicted in Scheme 2. By using a Suzuki coupling reaction in the presence of 4-methylthiophenylboronic acid, compound RBS was yielded as a light blue compound (78\%). Followed by the oxidation of the sulfur group in compound RBS by using $m$-CPBA as an oxidizing reagent in dry dichloromethane, probe RBSO was obtained in $76 \%$ yield. The structures of all synthetic compounds were confirmed by HRMS and NMR, and detailed data are presented in the ESI. $\dagger$

\section{Sensitivity studies}

With RBSO in hand, we first investigated whether the electron donor DTT could cause interferences in the assay because some molecules with a methyl sulfoxide group can be directly reduced by DTT. Different high concentration DTT $(0,1,2,5$, $10 \mathrm{mM})$ and RBSO $(10 \mu \mathrm{M})$ were interacted at $37{ }^{\circ} \mathrm{C}(50 \mathrm{mM}$ PBS, $\mathrm{pH}=7.4$ ), respectively, and the ratio of the fluorescence intensity $\left(F / F_{0}\right)$ was used to assess the effect of DTT on the probe. As shown in Fig. 1a, there were no interferences in the DTT concentration range of 1-10 mM, indicating that the highly reductive DTT did not respond significantly to the probe and could be used as the electron donor in the next assay. The concentration was fixed at $5 \mathrm{mM}$ in the following assays because DTT could cause negligible fluorescence signal changes at this concentration and was consistent with previous work. ${ }^{10}$

In order to test the in vitro response of RBSO as a potential Msr A sensor, emission spectra were recorded in the presence of various reducing species under the same conditions. As shown in Fig. S16 (ESI $\dagger$ ), the absorption maximum of RBSO at $596 \mathrm{~nm}$ and the fluorescence intensity of RBSO at $684 \mathrm{~nm}$ decreased remarkably after addition of DTT and Msr A, and furthermore exhibited a large Stokes shift at $88 \mathrm{~nm}$. Meanwhile, the ratio of the fluorescence intensity of the probe at $684 \mathrm{~nm}$ $\left(\left(F_{0}-F\right) / F_{\mathrm{Msra}}\right)$ was significantly enhanced (Fig. 1b). This spectral phenomenon can be ascribed to the reduction of the methyl sulfoxide to the methyl sulfide group by Msr A, which enabled the transformation of an electron-withdrawing group to an electron-donating group and thus induced the ICT process. In contrast, no significant fluorescence signal change
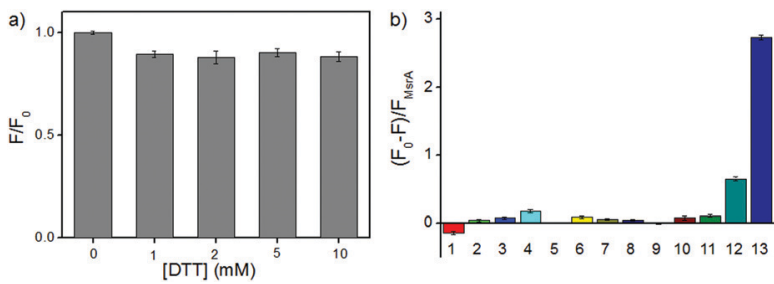

Fig. 1 (a) RBSO $(10 \mu \mathrm{M})$ was incubated with DTT $(0-10 \mathrm{mM})$, and the fold of the fluorescence increment $\left(F / F_{0}\right)$ was determined; $(b)\left(F_{0}-F\right) / F_{\text {Msra }}$ was determined after interaction of different analytes with RBSO $(10 \mu \mathrm{M})$, including (1) BSA (200 nM), (2) DTT (5 mM), (3) Cys (1 mM), (4) GSH (5 mM), (5) blank, (6) Hcy (1 mM), (7) GR/NADH (200 nM), (8) Vc (5 mM), (9) ethanethiol (5 mM), (10) Trx (200 nM), (11) TCEP (5 mM), (12) DTT + Msr $\mathrm{B}\left(5 \mathrm{mM}+3 \mu \mathrm{g} \mathrm{mL}^{-1}\right)$, (13) DTT + Msr A $\left(5 \mathrm{mM}+3 \mu \mathrm{g} \mathrm{mL}^{-1}\right)$. Conditions: PBS buffer $\left(50 \mathrm{mM}, \mathrm{pH} 7.4,37^{\circ} \mathrm{C}\right), \lambda_{\mathrm{ex}}=600 \mathrm{~nm}$, slit $=10 / 10 \mathrm{~nm}$. 
occurred when other thiol substances or reducing substances were added under the same conditions, including bovine serum albumin (BSA), DTT, Cys, GSH, glutathione reductase/ NADH (GR/NADH), Hcy, vitamin c (Vc), ethanethiol, Trx, tris(2carboxyethyl)phosphine (TCEP) and DTT/Msr B. Thus, the above-described results showed that RBSO could be specifically reduced by Msr A, resulting in an obvious fluorescence signal change. To verify the response mechanism of RBSO towards Msr A, high performance liquid chromatography (HPLC) and highresolution mass spectra (HRMS) experiments were conducted. As shown in Fig. S17 (ESI $\dagger$ ), an intense peak at $\mathrm{m} / \mathrm{z} 613.2169$ corresponding to RBS was distinct, providing reliable evidence for the Msr A-induced reduction. At the same time, this hypothesis was confirmed by HPLC, where a HPLC chromatograph of the pure RBSO showed a retention time of $4.07 \mathrm{~min}$, and a new peak of RBSO treated with DTT and Msr A appeared clearly at a retention time of $6.21 \mathrm{~min}$ (Fig. S18, ESI $\dagger$ ). The new peak corresponds to the formation of RBS because the retention time of the standard sample RBS is $6.21 \mathrm{~min}$.

Subsequently, in order to explore whether the probe could be used to monitor Msr A in real-time, time-dependent fluorescent responses of RBSO to enzyme were evaluated under physiological environments. After the addition of different concentrations ( 0 and $3 \mu \mathrm{g} \mathrm{mL}^{-1}$ ) of Msr A under the same conditions, the fluorescence intensity of the probe at $684 \mathrm{~nm}$ was recorded and is depicted in Fig. 2a. As shown in Fig. 2a, in the absence of Msr A, the fluorescence intensity of the probe at $684 \mathrm{~nm}$ remained substantially constant within 20 minutes, indicating that RBSO had high photo-stability. In contrast, upon addition of Msr A $\left(3 \mu \mathrm{g} \mathrm{mL}{ }^{-1}\right)$, the fluorescence intensity of the probe at $684 \mathrm{~nm}$ rapidly decreased and reached a plateau within about $8 \mathrm{~min}$, suggesting that RBSO could be used as an effective candidate for monitoring Msr A in real-time under physiological environments.

The $K_{\mathrm{m}}$ and $K_{\text {cat }}$ values are also key parameters for probes, so we subsequently calculated the $K_{\mathrm{m}}$ and $K_{\text {cat }}$ of RBSO under
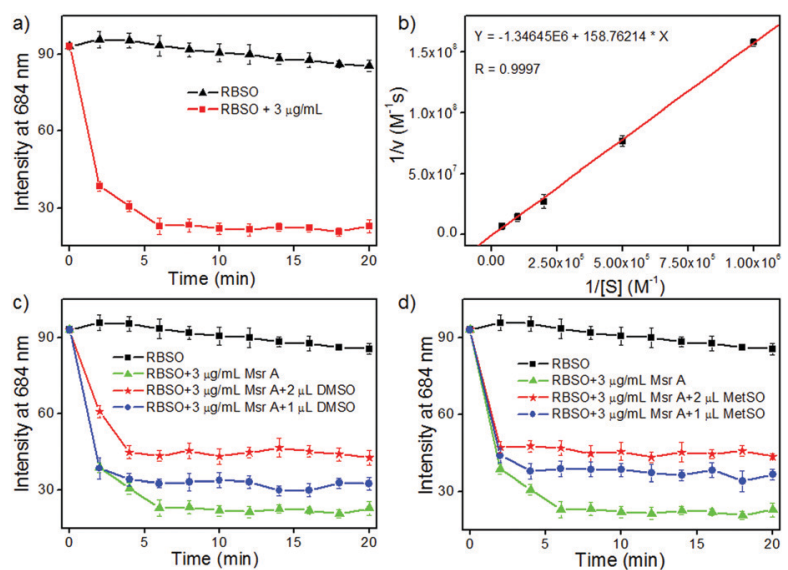

Fig. 2 (a) Time course of RBSO $(10 \mu \mathrm{M})$ fluorescence changes in the absence/ presence of Msr A ( $\left.3 \mu \mathrm{g} \mathrm{mL}^{-1}\right)$ and DTT ( $\left.5 \mathrm{mM}\right)$; (b) Lineweaver-Burk plot for the enzymatic reduction of RBSO catalyzed by Msr A. Inhibition of Msr A-mediated reduction of RBSO by DMSO (c) and MetSO (d). RBSO $(10 \mu \mathrm{M})$ was incubated with DTT $(5 \mathrm{mM})$ and Msr A $\left(3 \mu \mathrm{g} \mathrm{mL}{ }^{-1}\right)$ with or without DMSO and MetSO. Conditions: PBS buffer $\left(50 \mathrm{mM}, \mathrm{pH} 7.4,37^{\circ} \mathrm{C}\right), \lambda_{\mathrm{ex}}=600 \mathrm{~nm}$, slit $=10 / 10 \mathrm{~nm}$. physiological environments. As shown in Fig. $2 \mathrm{~b}$, the $K_{\mathrm{m}}$ $(72 \mu \mathrm{M})$ and $K_{\text {cat }}\left(6.2 \mathrm{~s}^{-1}\right)$ values of RBSO can be calculated by the Michaelis-Menten kinetics. Gratifyingly, compared with the $K_{\mathrm{m}}$ and $K_{\text {cat }}$ of other fluorescent probes reported, the properties of RBSO have been further improved. As shown in Table S1, the response time of RBSO is 8 minutes, while other probes required 30, 60 and 360 minutes, respectively, implying that the response time has been greatly improved. Furthermore, by comparing the reduction rates of different probes by Msr A, it was found that the reduction rate of RBSO was almost 10 times that of others reported. ${ }^{10}$ The above results demonstrated that RBSO can function as a highly selective fluorescent probe for Msr A, and has the potential for monitoring Msr A activity in real-time.

In addition, in order to further confirm that Msr A consumes RBSO, different doses of dimethyl sulfoxide (DMSO) and methionine sulfoxide (MetSO) were utilized to inhibit the reduction of RBSO. According to the literature, ${ }^{16}$ the presence of DMSO and MetSO inhibited the reduction of probes due to the competition between the sulfoxide groups of DMSO and MetSO. The corresponding time-dependent fluorescence responses of RBSO to enzymes in the presence of DMSO and MetSO are described in Fig. $2 \mathrm{c}$ and $\mathrm{d}$, respectively. Compared to the treatment with pure Msr A, upon the addition of different concentrations of DMSO or MetSO under the same conditions, they had obvious interference with signal response to Msr A, indicating that the presence of DMSO or MetSO affect the consumption of the probe. Furthermore, the effects of $\mathrm{pH}$ on the reaction system were investigated (Fig. S19, ESI $\dagger$ ), which revealed that RBSO functioned well under physiological conditions. Collectively, the above-described results suggested that RBSO could be used as a practical probe for the specific detection of Msr A in real-time under physiological environments.

\section{Cell imaging}

To examine the feasibility of using RBSO as an imaging reagent to map the activity of Msr A, cell imaging applications of RBSO for monitoring Msr A in living cells were carried out. Prior to cell imaging assays, standard MTT assay was performed to assess the cytotoxicity of RBSO in human cervix carcinoma HeLa cells. As shown in Fig. S20 (ESI $\dagger$ ), HeLa cells treated with various concentrations of $\mathbf{R B S O}(0,1,3,5,10$, and $20 \mu \mathrm{M})$ for $24 \mathrm{~h}$ showed high cell viability (no less than $80 \%$ ), indicating that the probe has fairly low toxicity to living cells, and thus, RBSO is suitable as an imaging reagent. Subsequently, imaging experiments of RBSO for monitoring Msr A in living cells were conducted. Since the cells contain Msr A, there is no need to add Msr A in cell imaging experiments. HeLa cells were incubated with RBSO $(0.1 \mu \mathrm{M})$ for 30 minutes, and then washed three times with PBS to remove excess probes. As shown in Fig. 3a, weak red fluorescence signals were observed in the red channel. In contrast, when the HeLa cells were pretreated with DMSO $(10 \mu \mathrm{L})$, a significant enhancement of the fluorescence signal in the red channel was observed because the reduction of RBSO was obviously inhibited (Fig. 3b). Compared with the controlled cells, the relative decrease of fluorescence signals is about 4-fold (Fig. 3c). The results indicated that RBSO was 


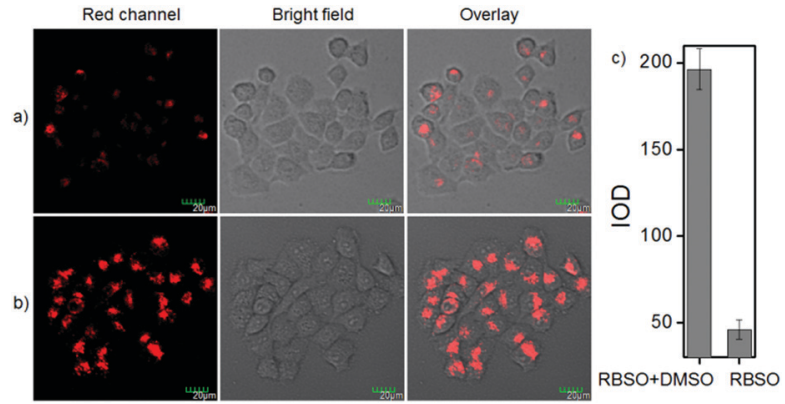

Fig. 3 Fluorescence images of HeLa cells stained with RBSO $(0.1 \mu \mathrm{M})$. (a) Cells were incubated with RBSO for 30 min; (b) cells were pretreated with DMSO $(10 \mu \mathrm{L})$, and then incubated with RBSO for $30 \mathrm{~min}$; and (c) Histogram of fluorescence enhancement. $\lambda_{\mathrm{ex}}=559 \mathrm{~nm}, \lambda_{\mathrm{em}}=650-750 \mathrm{~nm}$.

membrane permeable and could be used for imaging Msr A in living cells.

By carefully observing the overlay images of the red channel and the bright field, non-uniform intracellular fluorescence signals were noticed, implying that RBSO was likely to target organelles. Therefore, in order to verify whether RBSO has the desired organelle localization properties, we utilized commercial targeting reagents Lyso-Tracker Green (Lyso), Mito-tracker Green (Mito), and ER-Tracker Green (ER) to explore the organelletargeting of RBSO. Surprisingly, a high Pearson's coefficient (0.93) and overlap coefficient (0.93) were found in the intensity scatter plot of the green channel and red channel, suggesting that RBSO distributed mainly in lysosomes. In addition, the intensity scatter plot allowed us to highlight the corresponding yellow pixels on simulated images in accordance with the overlay image (Fig. 4a), and the changes in the intensity profiles in the linear region of interest across the cell were synchronous in the two channels (Fig. S21, ESI $\dagger$ ). According to that reported previously, ${ }^{17}$ moderate alkalinity of the nitrogen atom is critical for its specific localization in acidic lysosomes. Once RBSO diffuses into

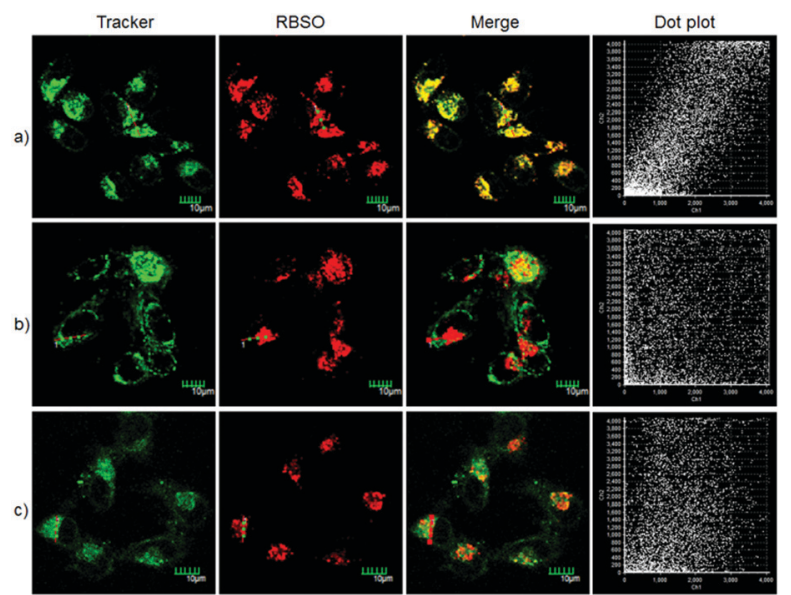

Fig. 4 Fluorescence imaging of the HeLa cells being costained with RBSO $(0.1 \mu \mathrm{M})$ and other organelle-targeting Trackers (200 nM). (a) Costained with Lyso-Tracker Green; (b) costained with Mito-Tracker Green; and (c) costained with ER-Tracker Green. Red channel: $\lambda_{\mathrm{ex}}=559 \mathrm{~nm}, \lambda_{\mathrm{em}}=$ 647-747 nm. Green channel: $\lambda_{\mathrm{ex}}=488 \mathrm{~nm}, \lambda_{\mathrm{em}}=520-546 \mathrm{~nm}$. lysosomes and is protonated, it becomes more hydrophilic and is retained in the lysosomes. In contrast, an obvious difference of the location between the fluorescence from other trackers (Mito and ER) and RBSO was observed (Fig. 4b and c). Similarly, low Pearson's coefficients and overlap coefficients were found in the intensity scatter plot, implying that RBSO does not accumulate in these organelles. These results suggest that RBSO can be used as an efficient organelle-targetable NIR probe for lysosomal Msr A imaging in living cells. Taken together, considering its low cytotoxicity and the excellent performance in cell imaging, the probe may be operated well in monitoring the activity of Msr A in the lysosome of living cells.

\section{Conclusions}

In summary, we designed and synthesized a novel lysosometargeted NIR fluorescent probe RBSO for fast detection and imaging Msr A by extending the linear $\pi$-conjugated system of the probe via the $\mathrm{S}_{\mathrm{N}} \mathrm{Ar}^{\mathrm{H}}$ reaction. As expected, RBSO exhibited high selectivity and high sensitivity for the specific detection of Msr A in real-time via a specific reduction reaction. Importantly, RBSO was cell-membrane permeable and capable of specifically distributing in lysosomes, and thus detects Msr A in real-time there, providing a potential tool for monitoring Msr A activity in lysosomes of living cells.

\section{Experimental}

\section{Synthetic procedures}

Synthesis of compound 1. $3^{\prime}$-(Diethylamino)-7'-hydroxyspiro[isobenzofuran-1(3H),9' $-[9 H]$ xanthen]-3-one (688.6 mg, $2.2 \mathrm{mmol}){ }^{18}$ anhydrous potassium carbonate $(828 \mathrm{mg}, 6 \mathrm{mmol})$ and 4-bromo-1fluoro-2-nitrobenzene ( $438 \mathrm{mg}, 2 \mathrm{mmol}$ ) were added to DMF $(10 \mathrm{~mL})$ and stirred under argon at $80{ }^{\circ} \mathrm{C}$ overnight. After cooling to room temperature, the mixture was extracted with $\mathrm{DCM}(50 \mathrm{~mL} \times 3)$. The collected organic phase was dried over anhydrous sodium sulfate and concentrated to dryness under vacuum. The crude product was isolated and purified by a silica gel column to afford yellow solid intermediate compound 1 (478 mg, 81\% yield). ${ }^{1} \mathrm{H}$ NMR (400 MHz, $\left.\mathrm{CDCl}_{3}\right) \delta 8.06-7.98(\mathrm{~m}, 2 \mathrm{H}), 7.73-7.68(\mathrm{~m}, 1 \mathrm{H}), 7.66-7.61(\mathrm{~m}, 1 \mathrm{H})$, 7.58-7.52 (m, 1H), 7.36-7.30 (m, 1H), 7.25-7.22 (m, 1H), 7.10-7.06 (m, 1H), 6.81-6.74 (m, 1H), 6.63-6.54 (m, 2H), $6.49(\mathrm{~s}, 1 \mathrm{H}), 6.41$ $(\mathrm{dd}, J=6.1,2.6 \mathrm{~Hz}, 1 \mathrm{H}), 3.39(\mathrm{dd}, J=8.7,3.7 \mathrm{~Hz}, 4 \mathrm{H}), 1.21(\mathrm{dt}, J=$ 10.4, 4.3 Hz, 6H). $\left.{ }^{13} \mathrm{C} \mathrm{NMR} \mathrm{(100} \mathrm{MHz,} \mathrm{CDCl}_{3}\right) \delta$ 169.32, 152.75, $152.60,150.45,149.81,149.66,149.23,140.80,137.09,135.15$, $129.89,128.81,128.43,126.81,125.12,124.01,122.33,121.30$, $120.36,119.19$, 119.06, 114.51, 108.73, 104.21, 97.54, 83.54, 44.53, 12.52. HRMS $m / z=589.0903$ calcd. for $\mathrm{C}_{30} \mathrm{H}_{24} \mathrm{~N}_{2} \mathrm{O}_{4} \mathrm{Br}^{+}$ $[\mathrm{M}]^{+}$, found: 589.0815 .

Synthesis of compound 2. Concentrated hydrochloric acid $(1 \mathrm{~mL})$ was added to a mixed solution of compound 1 (1.12 g, $2 \mathrm{mmol}$ ) and stannous chloride $(2.25 \mathrm{~g}, 10 \mathrm{mmol})$ in methanol $(20 \mathrm{~mL})$, and the mixture was heated under reflux for 8 hours with vigorous stirring. After cooling to room temperature, the mixture was extracted with DCM $(50 \mathrm{~mL} \times 3)$ and the collected 
organic phase was dried over anhydrous sodium sulfate. The dried mixture was concentrated under vacuum, and the crude product was separated and purified by a silica gel column to afford yellow solid intermediate compound 2 (885 $\mathrm{mg}, 77 \%$ yield). ${ }^{1} \mathrm{H} \mathrm{NMR}\left(400 \mathrm{MHz}, \mathrm{CDCl}_{3}\right) \delta 8.00(\mathrm{~d}, J=7.5 \mathrm{~Hz}, 1 \mathrm{H}), 7.67$ $(\mathrm{t}, J=7.4 \mathrm{~Hz}, 1 \mathrm{H}), 7.61(\mathrm{t}, J=7.3 \mathrm{~Hz}, 1 \mathrm{H}), 7.21(\mathrm{dd}, J=8.1,5.5 \mathrm{~Hz}$, $2 \mathrm{H}), 6.91(\mathrm{dd}, J=9.0,2.7 \mathrm{~Hz}, 1 \mathrm{H}), 6.87$ (d, $J=2.0 \mathrm{~Hz}, 1 \mathrm{H}), 6.74-$ $6.67(\mathrm{~m}, 1 \mathrm{H}), 6.58(\mathrm{~d}, J=8.5 \mathrm{~Hz}, 1 \mathrm{H}), 6.52(\mathrm{~d}, J=8.5 \mathrm{~Hz}, 1 \mathrm{H})$, $6.47(\mathrm{~d}, J=2.7 \mathrm{~Hz}, 2 \mathrm{H}), 6.39(\mathrm{~s}, 1 \mathrm{H}), 3.82$ (s, 2H), 3.36 (dd, $J=13.7,6.8 \mathrm{~Hz}, 4 \mathrm{H}), 1.18(\mathrm{t}, \mathrm{J}=7.0 \mathrm{~Hz}, 6 \mathrm{H}) .{ }^{13} \mathrm{C} \mathrm{NMR}(100 \mathrm{MHz}$, $\left.\mathrm{CDCl}_{3}\right) \delta 169.42,152.97,152.83,151.77,149.74,147.85,142.81$, 139.54, 134.92, 129.71, 128.86, 127.03, 125.06, 123.96, 121.00, 120.76, 119.96, 119.70, 118.64, 118.31, 117.13, 116.83, 108.52, $97.59,83.92,60.40,44.52,14.22,12.52$. HRMS $m / z=559.1061$ calcd. for $\mathrm{C}_{30} \mathrm{H}_{26} \mathrm{~N}_{2} \mathrm{O}_{4} \mathrm{Br}^{+}[\mathrm{M}]^{+}$, found: 559.1064.

Synthesis of compound RB. Concentrated sulfuric acid ( $1 \mathrm{~mL}$ ) was added to a mixed solution of the compound 2 $(1.13 \mathrm{~g}, 2 \mathrm{mmol})$ in methanol $(20 \mathrm{~mL})$, and the mixture was heated under reflux for 4 hours under vigorous stirring. After cooling to room temperature, the mixture was extracted with DCM $(50 \mathrm{~mL} \times 3)$. The collected organic phase was dried over anhydrous sodium sulfate and concentrated to dryness under vacuum. Then, anhydrous potassium carbonate (138 mg, $1 \mathrm{mmol}$ ) and ethyl acetate $(6 \mathrm{~mL})$ were added and stirred at $40{ }^{\circ} \mathrm{C}$ overnight. After cooling to room temperature, the mixture was extracted with ethyl acetate $(50 \mathrm{~mL} \times 3)$, and the organic phase was collected and dried over anhydrous sodium sulfate. The mixture was concentrated in a rotary evaporator to remove the solvent, and the crude product was purified by a silica gel column to afford blue solid compound RB (292 mg, 51\% yield). ${ }^{1} \mathrm{H}$ NMR (400 MHz, $\mathrm{CDCl}_{3}$ ) $\delta 8.30(\mathrm{~d}, J=7.6 \mathrm{~Hz}, 1 \mathrm{H}), 7.77(\mathrm{dt}, J=21.9,7.3 \mathrm{~Hz}, 2 \mathrm{H}), 7.27(\mathrm{~s}, 1 \mathrm{H})$, $7.12(\mathrm{~s}, 1 \mathrm{H}), 7.00(\mathrm{~d}, J=9.6 \mathrm{~Hz}, 2 \mathrm{H}), 6.85-6.75(\mathrm{~m}, 2 \mathrm{H}), 6.72(\mathrm{~s}, 1 \mathrm{H})$, $6.38(\mathrm{~d}, J=8.5 \mathrm{~Hz}, 1 \mathrm{H}), 6.15$ (s, 1H), 3.69 (s, 3H), 3.57 (dd, $J=14.2$, $7.0 \mathrm{~Hz}, 4 \mathrm{H}), 1.31(\mathrm{t}, J=7.0 \mathrm{~Hz}, 6 \mathrm{H}) .{ }^{13} \mathrm{C} \mathrm{NMR}\left(100 \mathrm{MHz}, \mathrm{CDCl}_{3}\right) \delta$ $165.41,160.08,159.69$, 157.52, 155.98, 155.10, 142.96, 142.19, $133.63,133.26,131.50,130.50,129.99,129.63,126.92,118.82$, $117.14,116.89,116.69,116.58,114.96,114.63,114.03,110.10$, 99.66, 96.31, 52.67, 46.05, 12.54. HRMS $m / z=571.1061$ calcd. for $\mathrm{C}_{31} \mathrm{H}_{26} \mathrm{~N}_{2} \mathrm{O}_{4} \mathrm{Br}^{+}[\mathrm{M}]^{+}$, found: 571.1013.

Synthesis of compound RBS. Compound RB (1 mmol, $568 \mathrm{mg})$, 4-methylthiophenylboronic acid (1.1 mmol, $185 \mathrm{mg})$, potassium carbonate (3 mmol, $414 \mathrm{mg})$ and $\mathrm{Pd}\left(\mathrm{PPh}_{3}\right)_{4}(0.03 \mathrm{mmol}, 30 \mathrm{mg})$ were placed in a two-necked round bottom flask and argon gas protection was carried out using a Schlenk line. Then, $15 \mathrm{ml}$ of toluene was added as a solvent using a syringe, and the reaction system was heated to $100{ }^{\circ} \mathrm{C}$ for 36 hours. The reaction mixture was cooled to room temperature and poured into $50 \mathrm{~mL}$ of water. The mixture was extracted with water and dichloromethane $(50 \mathrm{ml} \times 3)$ and the organic phase was dried over anhydrous sodium sulfate. The mixture was concentrated in a rotary evaporator to remove the solvent, and the crude product was purified by a silica gel column to afford blue solid product RBS (477 mg, yield 78\%). ${ }^{1} \mathrm{H}$ NMR (400 MHz, $\left.\mathrm{CDCl}_{3}\right) \delta 8.19(\mathrm{~d}, J=7.7$ $\mathrm{Hz}, 1 \mathrm{H}), 7.69(\mathrm{dd}, J=10.5,4.2 \mathrm{~Hz}, 1 \mathrm{H}), 7.60(\mathrm{t}, J=7.0 \mathrm{~Hz}, 1 \mathrm{H})$, $7.46(\mathrm{~d}, J=8.1 \mathrm{~Hz}, 2 \mathrm{H}), 7.34(\mathrm{~s}, 1 \mathrm{H}), 7.31-7.26(\mathrm{~m}, 3 \mathrm{H}), 7.07-6.97$ $(\mathrm{m}, 1 \mathrm{H}), 6.67-6.53(\mathrm{~m}, 3 \mathrm{H}), 6.48(\mathrm{~s}, 1 \mathrm{H}), 6.39(\mathrm{t}, J=12.1 \mathrm{~Hz}, 1 \mathrm{H})$, $5.75(\mathrm{~s}, 1 \mathrm{H}), 3.69(\mathrm{~s}, 3 \mathrm{H}), 3.41(\mathrm{~d}, J=6.8 \mathrm{~Hz}, 4 \mathrm{H}), 2.50(\mathrm{~s}, 3 \mathrm{H})$, $1.21(\mathrm{t}, J=6.6 \mathrm{~Hz}, 6 \mathrm{H}) .{ }^{13} \mathrm{C}$ NMR $\left(100 \mathrm{MHz}, \mathrm{CDCl}_{3}\right) \delta 166.08$, $156.43,154.72,150.83,150.80,144.47,144.35$, 144.30, 144.17, 144.01, 136.53, 135.46, 132.91, 132.85, 131.10, 130.91, 130.57, 129.08, 127.64, 126.96, 126.92, 123.54, 119.22, 114.75, 112.63, 109.99, 104.48, 102.39, 102.31, 96.94, 52.42, 44.97, 15.96, 12.65. HRMS $m / z=$ 613.2161 calcd. for $\mathrm{C}_{38} \mathrm{H}_{33} \mathrm{~N}_{2} \mathrm{O}_{4} \mathrm{~S}^{+}[\mathrm{M}+\mathrm{H}]^{+}$, found: 613.2169.

Synthesis of compound RBSO. Upon addition of $m$-CPBA (0.5 mmol, $86 \mathrm{mg}$ ) to compound RBS $(0.5 \mathrm{mmol}, 306 \mathrm{mg})$ in dry dichloromethane in an ice bath, the temperature naturally increased to room temperature, and the reaction was carried out for 5 hours under vigorous stirring. After removing the solvent under vacuum, the crude product was purified by a silica gel column to afford blue solid product RBSO $(238 \mathrm{mg}$, $76 \%$ yield). ${ }^{1} \mathrm{H}$ NMR (400 MHz, $\left.\mathrm{CDCl}_{3}\right) \delta 8.24(\mathrm{~d}, J=7.8 \mathrm{~Hz}, 1 \mathrm{H})$, $8.13(\mathrm{~s}, 0.5 \mathrm{H}), 8.02(\mathrm{~d}, J=5.5 \mathrm{~Hz}, 0.5 \mathrm{H}), 7.75(\mathrm{t}, J=7.4 \mathrm{~Hz}, 1 \mathrm{H})$, $7.71-7.60(\mathrm{~m}, 5 \mathrm{H}), 7.43(\mathrm{~s}, 1 \mathrm{H}), 7.10(\mathrm{~s}, 1 \mathrm{H}), 7.01(\mathrm{~d}, J=7.6 \mathrm{~Hz}$, $1 \mathrm{H}), 6.79(\mathrm{~d}, J=9.0 \mathrm{~Hz}, 1 \mathrm{H}), 6.61(\mathrm{dd}, J=13.4,9.2 \mathrm{~Hz}, 3 \mathrm{H}), 5.97$ (s, 1H), $3.68(\mathrm{~s}, 3 \mathrm{H}), 3.46(\mathrm{dd}, J=13.8,6.8 \mathrm{~Hz}, 4 \mathrm{H}), 2.73(\mathrm{~s}, 3 \mathrm{H})$, $1.24(\mathrm{t}, J=6.9 \mathrm{~Hz}, 6 \mathrm{H}) .{ }^{13} \mathrm{C}$ NMR $\left(100 \mathrm{MHz}, \mathrm{CDCl}_{3}\right) \delta 165.62$, 156.72 , 156.00, 152.85, 152.79, 144.14, 143.93, 143.91, 142.71, 135.99, 134.52, 133.55, 132.97, 131.24, 130.43, 129.89, 128.75, 129.05, 129.02, 128.91, 127.94, 127.50, 123.97, 123.44, 118.51, $118.45,118.41,118.39,117.98,117.95,115.26,113.29,112.35$, 112.28, 107.39, 107.36, 107.33, 100.70, 96.58, 52.48, 45.42, 43.96, 12.60. HRMS $m / z=629.2110$ calcd. for $\mathrm{C}_{38} \mathrm{H}_{33} \mathrm{~N}_{2} \mathrm{O}_{5} \mathrm{~S}^{+}$ $[\mathrm{M}+\mathrm{H}]^{+}$, found: 629.2118 .

\section{Cell culture and fluorescence imaging}

HeLa cells were cultured in DMEM medium supplemented with $10 \%(\mathrm{v} / \mathrm{v})$ fetal bovine serum and penicillin/streptomycin $\left(100 \mu \mathrm{g} \mathrm{mL}{ }^{-1}\right)$ in an atmosphere of $5 \% \mathrm{CO}_{2}$ at $37{ }^{\circ} \mathrm{C}$. Then, HeLa cells were seeded in a 24 -well plate, cultured in an incubator for 2 hours to adhere to the plate, and then subjected to fluorescence imaging experiments. In the treated group, the cells were incubated with RBSO $(0.1 \mu \mathrm{M})$ for $30 \mathrm{~min}$. In the controlled group, the cells were pre-incubated with DMSO for half an hour. Then, the probe was added and incubated for an additional half an hour. For co-localization experiments, RBSO $(0.1 \mu \mathrm{M})$ was incubated with $200 \mathrm{nM}$ of Mito-Tracker Green (Mito), Lyso-Tracker Green (Lyso), and ER-Tracker Green (ER) for 30 minutes, respectively. Fluorescence imaging experiments were performed on a confocal laser scanning microscope after washing three times with PBS buffer.

\section{Conflicts of interest}

There are no conflicts to declare.

\section{Acknowledgements}

This work was sponsored by the National Natural Science Foundation of China (NNSFC 21907075 and 21272172) and the Natural Science Foundation of Tianjin City (19JCZDJC32400 and 18JCQNJC75900). 


\section{Notes and references}

1 (a) H. Weissbach, F. Etienne, T. Hoshi, S. H. Heinemann, W. T. Lowther, B. Matthews, G. John, C. Nathan and N. Brot, Arch. Biochem. Biophys., 2002, 397, 172; (b) S. Boschi-Muller, A. Gand and G. Branlant, Arch. Biochem. Biophys., 2008, 474, 266; (c) A. Kaya, B. C. Lee and V. N. Gladyshev, Antioxid. Redox Signaling, 2015, 23, 814.

2 (a) C. Beedham, Pharm. World Sci., 1997, 19, 255; (b) R. Bentley, Chem. Soc. Rev., 2005, 34, 609; (c) T. Lynch and A. Price, Am. Fam. Physician, 2007, 76, 391.

3 (a) S. P. Gabbita, M. Y. Aksenov, M. A. Lovell and W. R. Markesbery, J. Neurochem., 1999, 73, 1660; (b) E. R. Stadtman, J. Moskovitz and R. L. Levine, Antioxid. Redox Signaling, 2003, 5, 577; (c) F. Liu, J. Hindupur, J. L. Nguyen, K. J. Ruf, J. Zhu, J. L. Schieler, C. C. Bonham, K. V. Wood, V. J. Davisson and J. C. Rochet, Free Radical Biol. Med., 2008, 45, 242.

4 (a) H. Weissbach, L. Resnick and N. Brot, Biochim. Biophys. Acta, 2005, 1703, 203; (b) J. A. Imlay, Annu. Rev. Biochem., 2008, 77, 755; (c) A. Hansel, S. H. Heinemann and T. Hoshi, Biochim. Biophys. Acta, Proteins Proteomics, 2005, 1703, 239; (d) L. Tarrago, Z. Peterfi, B. C. Lee, T. Michel and V. N. Gladyshev, Nat. Chem. Biol., 2015, 11, 332.

5 (a) F. Etienne, L. Resnick, D. Sagher, N. Brot and H. Weissbach, Biochem. Biophys. Res. Commun., 2003, 312, 1005; (b) D. B. Oien and J. Moskovitz, Curr. Top. Dev. Biol., 2008, 80, 93.

6 (a) N. Brot, L. Weissbach, J. Werth and H. Weissbach, Proc. Natl. Acad. Sci. U. S. A., 1981, 78, 2155; (b) W. T. Lowther, N. Brot, H. Weissbach and B. W. Matthews, Biochemistry, 2000, 39, 13307; (c) R. Grimaud, B. Ezraty, J. K. Mitchell, D. Lafitte, C. Briand, P. J. Derrick and F. Barras, J. Biol. Chem., 2001, 276, 48915.

7 (a) E. R. Stadtman, Arch. Biochem. Biophys., 2004, 423, 2; (b) X. H. Zhang and H. Weissbach, Biol. Rev. Cambridge Philos. Soc., 2008, 83, 249; (c) L. Tarrago, E. Laugier, M. Zaffagnini, C. Marchand, P. Le Maréchal, N. Rouhier, S. D. Lemaire and P. Rey, J. Biol. Chem., 2009, 284, 18963.

8 (a) A. P. D. Silva, H. Q. N. Gunaratne, T. Gunnlaugsson, A. J. M. Huxley, C. P. McCoy, J. T. Rademacher and T. E. Rice, Chem. Rev., 1997, 97, 1515; (b) J. Yin, Y. Hu and J. Y. Yoon, Chem. Soc. Rev., 2015, 44, 4619; (c) X. Chen, Y. Zhou, X. Peng and J. Yoon, Chem. Soc. Rev., 2010, 39, 2120; (d) L. Niu, Y. Chen, L. Wu, C. Tung and Q. Yang, Chem. Soc. Rev., 2015, 44, 6143; (e) Y. Tang, D. Lee, J. Wang, G. Li, J. Yu, W. Lin and J. Yoon, Chem. Soc. Rev., 2015, 44, 5003; $(f)$ L. He, B. Dong, Y. Liu and W. Lin, Chem. Soc. Rev., 2016, 45, 6449; (g) J. Gong, C. Liu, X. Jiao, S. He, L. Zhao and X. Zeng,, Microchem. J., 2020, 158, 105191; (h) J. Gong, C. Liu, X. Jiao, S. He, L. Zhao and X. Zeng, Org. Biomol. Chem., 2020, 18, 5238; (i) H. Liu, L. Chen, C. Xu, Z. Li, H. Zhang, X. Zhang and W. Tan, Chem. Soc. Rev., 2018, 47, 7140; ( $j$ ) Y. Yue, F. Huo, F. Cheng, X. Zhu, T. Mafireyi, R. M. Strongin and C. Yin, Chem. Soc. Rev., 2019, 48, 4155; (k) Y. Tang, Y. Ma, J. Yin and W. Lin, Chem. Soc. Rev., 2019, 48, 4036.

9 (a) B. Valeur and I. Leray, Coord. Chem. Rev., 2000, 205, 3; (b) A. P. de Silva, H. Q. N. Gunaratne, T. Gunnlaugsson, A. J. M. Huxley, C. P. McCoy, J. T. Rademacher and T. E. Rice, Chem. Rev., 1997, 97, 1515; (c) S. Cai, C. Liu, X. Jiao, S. He, L. Zhao and X. Zeng, Org. Biomol. Chem., 2020, 18, 1148; (d) S. Cai, C. Liu, X. Jiao, L. Zhao and X. Zeng, J. Mater. Chem. B, 2020, 8, 2269; (e) H. Li, Y. Li, Q. Yao, J. Fan, W. Sun, S. Long, K. Shao, J. Du, J. Wang and X. Peng, Chem. Sci., 2019, 10, 1619; $(f)$ N. Kaur, S. Chopra, G. Singh, P. Raj, A. Bhasin, S. K. Sahoo, A. Kuwar and N. Singh, J. Mater. Chem. B, 2018, 6, 4872; (g) T. Chen, Z. Chen, R. Liu and S. Zheng, Org. Biomol. Chem., 2019, 17, 6398.

10 (a) L. Zhang, S. Peng, J. Sun, J. Yao, J. Kang, Y. Hu and J. Fang, Chem. Sci., 2017, 8, 2966; (b) N. Makukhin, V. Tretyachenko, J. Moskovitz and J. Míšek, Angew. Chem., 2016, 128, 12919; (c) L. Zhang, S. Peng, J. Sun, R. Liu, S. Liu and J. Fang, Chem. Commun., 2019, 55, 1502; (d) M. Xiang, H. Huang, X. Liu, Z. Tong, C. Zhang, F. Wang, R. Yu and J. Jiang, Anal. Chem., 2019, 91, 5489.

11 (a) Z. Q. Guo, S. Park, J. Yoon and I. Shin, Chem. Soc. Rev., 2014, 43, 16; (b) R. Weissleder and V. Ntziachristos, Nat. Med., 2003, 9, 123; (c) C. Liu, Q. Wang, X. Jiao, H. Yao, S. He, L. Zhao and X. Zeng, Dyes Pigm., 2019, 160, 989; (d) C. Liu, X. Jiao, Q. Wang, K. Huang, S. He, L. Zhao and X. Zeng, Chem. Commun., 2017, 53, 10727.

12 A. Kaya, A. Koc, B. C. Lee, D. E. Fomenko, M. Rederstorff, A. Krol, A. Lescure and V. N. Gladyshev, Biochemistry, 2010, 49, 8618.

13 S. Vougier, J. Mary and B. Friguet, Biochem. J., 2003, 373, 531. 14 J. Moskovitz, H. Weissbach and N. Brot, Proc. Natl. Acad. Sci. U. S. A., 1996, 93, 2095.

15 (a) Q. Wang, K. Huang, S. Cai, C. Liu, X. Jiao, S. He, L. Zhao and X. Zeng, Org. Biomol. Chem., 2018, 16, 7163; (b) J. Gong, C. Liu, X. Jiao, S. He, L. Zhao and X. Zeng,, J. Mater. Chem. B, 2020, 8, 2343.

16 D. Brunell, H. Weissbach, P. Hodder and N. Brot, Assay Drug Dev. Technol., 2010, 8, 615.

17 (a) L. Wang, Y. Xiao, W. Tian and L. Deng, J. Am. Chem. Soc., 2013, 135, 2903; (b) Q. Zhou, B. Xin, Y. Wang, C. Li, Z. Chen, Q. Yu, Z. Huang and M. Zhu, Chem. Commun., 2018, 54, 3617.

18 J. Qin, H. Yao, S. He and X. Zeng, RSC Adv., 2016, 6, 75570. 